\title{
Accenture - Understanding Sustainable Business Strategies
}

\author{
Harshith Kumar M. ${ }^{1}$, Krishna Prasad K. ${ }^{2}$ \& Subramanya Bhat ${ }^{2}$ \\ ${ }^{1}$ II Year MCA, College of Computer \& Information Sciences, Srinivas University, \\ Mangalore, Karnataka, India. \\ ${ }^{2}$ College of Computer \& Information Sciences, Srinivas University, Mangalore, Karnataka, \\ India. \\ E-Mail: harshith.alva1@gmail.com
}

Type of the Paper: Case Study.

Type of Review: Peer Reviewed.

Indexed In: OpenAIRE.

DOI: http://dx.doi.org/10.5281/zenodo.1254137.

Google Scholar Citation: $\underline{\text { IJCSBE}}$

\section{How to Cite this Paper:}

Harshith Kumar, M., Krishna Prasad, K., \& Bhat, Subramanya. (2018). AccentureUnderstanding Sustainable Business Strategies. International Journal of Case Studies in Business, IT and Education (IJCSBE), 2(1), 54-63.

DOI: http://dx.doi.org/10.5281/zenodo.1254137.

International Journal of Case Studies in Business, IT and Education (IJCSBE)

A Refereed International Journal of Srinivas University, India.

(C) With Authors.

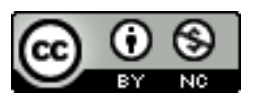

This work is licensed under a Creative Commons Attribution-Non Commercial 4.0 International License subject to proper citation to the publication source of the work.

Disclaimer: The scholarly papers as reviewed and published by the Srinivas Publications (S.P.), India are the views and opinions of their respective authors and are not the views or opinions of the S.P. The S.P. disclaims of any harm or loss caused due to the published content to any party. 


\title{
Accenture - Understanding Sustainable Business Strategies
}

\author{
Harshith Kumar M. ${ }^{1}$, Krishna Prasad K. ${ }^{2}$ \& Subramanya Bhat ${ }^{2}$ \\ ${ }^{1}$ II Year MCA, College of Computer \& Information Sciences, Srinivas University, \\ Mangalore, Karnataka, India. \\ ${ }^{2}$ College of Computer \& Information Sciences, Srinivas University, Mangalore, Karnataka, \\ India. \\ E-Mail: harshith.alva1@gmail.com
}

ABSTRACT

Accenture is a worldwide global management, consulting, and expert administrations Services Company that provides strategy, consulting, digital, technology, and operations services. The word "Accenture" is evidently copied or derived from "Accent of the future". The name speaks its Will to be a worldwide Consulting pioneer and superior worker and furthermore proposed that the name ought not to be hostile in any nation in which Accenture works. Accenture Strategy gives business technique, innovation system, and activities procedure services. Accenture Consulting unit provides innovation, business, and administration services to its customers. Accenture Digital system provides digital marketing, analytics, and mobility services to its customers spread all over the world. Accenture Technology focuses on new and innovative technological solutions, and its implementations, delivery and research and development, including its technological Labs for emerging technologies. Accenture Operations centers on service model of service delivery system. This includes business process outsourcing, IT services, cloud services, managed operations, security, and infrastructure services. The company also operates a "National Security Services" business. In this case study of Accenture, we tried to understand the sustainable business strategies by analyzing the various products of the company, analyzing the HR strategy of the company, analyzing the various services of the company, analyzing the performance of the company with other companies, and analyzing the environmental strategy of the company. Finally, the internal abilities of Accenture are discussed by means of SWOT analysis.

Keywords: Accenture, Accenture-Company analysis, Accenture-Case Study, Accenturebusiness analysis, Accenture-HR strategy.

\section{INTRODUCTION :}

The Accenture is a fortune Global 500 company; it has been started in Dublin, Ireland, since $1^{\text {st }}$ September 2009. In 2017, the organization revealed net incomes of $\$ 34.9$ billion, with in excess of 425,000 employees serving customers in excess of 200 urban areas in 120 countries [1-5]. In 2015, the organization had around 130,000 workers in India, around 48,000 in the US, and around 50,000 in the Philippines. Accenture's present customers incorporate 95 of the Fortune Global 100 and more than seventy-five percent of the Fortune Global 500. The principal objective of Accenture is to accomplish a gender balanced or gender equal workspace. Accenture contracts or hires workers as per their legitimacy. Accenture accomplices with in excess of $75 \%$ of the Fortune Global 500, driving advancement to enhance the way the world works and lives [6-9]. With skill crosswise over in excess of 40 enterprises and all business capacities, they convey transformational outcome for a highly demanding, competitive and advanced world. Accenture is serving customers in around of 120 nations. Accenture has shown up in "World's Most Admired Companies" list. They have 5k patents and patent pending applications in 44 countries around the globe. In the present business condition, organizations need to consistently rethink themselves. At Accenture, they adopt an advancement drove strategy to enable customers "to envision and concoct or invent" their future. Through the 
Accenture Innovation Architecture, they consolidate their capacities to concoct, create, and convey disruptive advancements for customers, and to scale them quicker. Today, Accenture is helping the world's driving organizations envision the future and breathe life into it. The firm has put advancement immovably at the center of their plan of action with what it has authored the Accenture Innovation Architecture, uniting Accenture Research to distinguish market and innovation patterns, Accenture Ventures to put resources into development arrange organizations, Accenture Labs to brood and model new with speed and agility[10-20].

This paper contains 12 sections. Section 1 explains the brief introduction of Accenture. Section 2 explains objectives of the paper. Section 3 describes Mission and Vision of Accenture. Section 4 narrates different products of Accenture. Section 5 describes services and solutions in a different perspective. Section 6 explains partners and alliances of Accenture. Section 7 describes environmental strategies of the concerned company. Section 8 describes Human Resource Strategies of the Accenture. Section 9 explains about competitors of our concerned company, Section 10 explains The Accenture strategies against its competitors, Section 11 describes SWOT analysis of our concerned company and Section 12 concludes the paper.

\section{OBJECTIVES :}

- To know about the leadership team at Accenture.

- To analyse the products of Accenture.

- To analyse the various services and solutions of Accenture.

- To know about the Accenture Partners and Alliances.

- To analyse the environmental strategy of Accenture.

- To analyse the HR strategies of Accenture.

- To analyse Accenture's strategy against its competitors.

- To analyse Accenture company using SWOT Analysis.

\section{MISSION AND VISION :}

Mission: Helping the clients, spread all across the globe to create their future.

Vision: To become one of the world's leading companies, bringing innovations to improve the way the world works and lives.

\section{PRODUCTS OF ACCENTURE :}

Accenture is an administration Consulting, innovation Consulting, and innovation outsourcing company. It doesn't fabricate or deliver an item. It enables organizations and governments to accomplish unrivalled outcomes crosswise over five working gatherings:

- Communication and highly advanced Technology

- Financial Services

- Products (IT related)

- Public Service

- Resources

\section{SERVICES AND SOLUTIONS :}

Accenture's five organizations "Accenture Strategy, Accenture Consulting, Accenture Digital, Accenture Technology and Accenture Operations" create and convey incorporated administrations and answers for its customers or clients.

Accenture Strategy enables customers to accomplish particular business results and upgrade investor esteem by characterizing and executing industry-particular methodologies empowered by innovation. They unite their methodology capacities in business and innovation to help senior administration groups shape and execute their change destinations, concentrating on issues identified with advanced interruption, aggressive spryness, worldwide working models, and the future workforce.

Accenture Consulting gives industry specialists the bits of knowledge and administration and innovation Consulting capacities to help change the world's driving organizations. Its consulting abilities empower its customers to plan and execute transformational change programs, either for at 
least one capacity or specialty units or over their whole association. They give industry-particular Consulting administrations and in addition practical and innovation Consulting administrations.

Accenture Digital consolidates their capacities in computerized showcasing, investigation and versatility to enable customers to open an incentive by planning new encounters for clients and workers, implanting insight into their tasks, making new items and plans of action, and changing their advanced undertaking abilities and associations.

\section{ACCENTURE PARTNERS AND ALLIANCES :}

Oracle: Oracle Corporation is an American multinational Computer or digital innovation enterprise, headquartered in Redwood Shores, California. The organization practices essentially in creating and advertising database programming and innovation, cloud built frameworks and endeavour programming items, especially its own brands of database administration frameworks. In 2015, Oracle was the second-biggest programming creator by income, after Microsoft.

Google: Google is an American multinational innovation organization that has practical experience in Internet-related administrations and items, which incorporate web-based publicizing or advertising advancements, web index, distributed computing, programming, and equipment. Google was established in 1998 by Larry Page and Sergey Brin while they were Ph.D. understudies at Stanford University, California. Together, they possess around 14 percent of its offers and control 56 percent of the investor voting power through super-voting stock.

Amazon Web Services: Amazon Web Services (AWS) is an auxiliary or sister institution of Amazon.com that gives on-request distributed computing stages to people, organizations, and governments, on a paid membership premise. The innovation enables endorsers of have available to them an undeniable virtual bunch of PCs, accessible constantly, through the Internet. AWS's rendition of virtual PCs have the vast majority of the traits of a genuine PC including equipment (CPU(s) and GPU(s) for handling, neighborhood/RAM memory, hard-circle/SSD stockpiling); a decision of working frameworks; organizing; and pre-stacked application programming, for example, web servers, databases, CRM, and so forth [10].

Red Hat: Red Hat, Inc. is an American multinational programming organization giving open-source programming items to the undertaking group. Established in 1993, Red Hat has its corporate base camp in Raleigh, North Carolina, with satellite workplaces worldwide. Red Hat has moved toward becoming related to a vast degree with its venture working framework Red Hat Enterprise Linux and with the obtaining of open-source endeavour middleware merchant JBoss. Red Hat likewise offers Red Hat Virtualization (RHV), an undertaking virtualization item. Red Hat gives stockpiling, working framework stages, middleware, applications, administration items, and support, preparing, and Consulting administrations [10].

Huawei: Huawei Technologies Co., Ltd. is a Chinese multinational systems administration, media communications hardware, and administrations organization headquartered in Shenzhen, Guangdong. It is the biggest broadcast or telecommunication product or equipment producer in the world, having overwhelmed Ericsson in 2012. In 2017, Huawei ended up 83rd of Fortune Global 500 in Fortune Magazine. Huawei was established in 1987 by Ren Zhengfei, a previous designer in the People's Liberation Army. At the season of its foundation, Huawei concentrated on assembling telephone switches, however, has since extended its business to incorporate building media communications systems, giving operational and consulting administrations or organization and gear to ventures inside and outside of China, and assembling specialized gadgets for the purchaser advertise [10].

IBM: The International Business Machines Corporation (IBM) is an American multinational innovation technology-based organization headquartered in Armonk, New York, United States, with its branches spread in more than 170 nations. The organization started in 1911 as the ComputingTabulating-Recording Company (CTR) and was renamed "Worldwide Business Machines" in 1924. IBM produces and markets PC equipment, middleware, and programming, and gives facilitating and Consulting or consultation administrations in regions going from centralized server PCs to nanotechnology [10].

SAP: SAP ERP is Enterprise resource planning or programming created by the German organization SAP SE. SAP ERP consolidates the key business elements of an association. The most recent form 
(SAP ERP 6.0) was made accessible in 2006. The latest Enhancement Package (EHP8) for SAP ERP 6.0 was discharged in 2016 [10].

Cisco: Cisco Systems, Inc. is an American multinational company headquartered in San Jose, California, in the focal point of Silicon Valley, that creates, makes and offers organizing equipment, media communications gear and other high-innovation administrations and products. Through its various gained auxiliaries, for example, OpenDNS, WebEx, Jabber and Jasper, Cisco practices into particular tech markets, for example, Internet of Things (IoT), space security and vitality administration [10].

Microsoft: Microsoft Corporation is an American multinational innovation organization with a central branch in Redmond, Washington. It creates, produces, licenses, backings and offers PC programming, buyer hardware, PCs, and administrations. Its best-known programming items are the Microsoft Windows line of working frameworks, the Microsoft Office suite, and the Internet Explorer and Edge web programs. Its leader equipment items are the Xbox computer game consoles and the Microsoft Surface line-up of touch screen PCs. Starting in 2016, it is the world's biggest programming producer by revenue and one of the world's most important organizations [10].

Dell: Dell is an American multinational PC innovation organization situated in Round Rock, Texas, the United States, which creates, offers, repairs, and backings PCs and related items and administrations. Eponymously named after its originator, Michael Dell, the organization is one of the biggest innovative enterprises on the planet, utilizing in excess of 103,300 individuals worldwide [10].

Nokia: Nokia is a multinational media communications, data innovation, and consumer electronic organization, established in 1865. Nokia's central branch is located in Espoo, in the Helsinki metropolitan area. In 2017, Nokia utilized roughly 102,000 individuals crosswise over more than 100 nations, worked together in excess of 130 nations, and announced yearly incomes of around €23 billion [10].

Vodafone: Vodafone Group is a British multinational media communications organization, with a base camp in London. It prevalently works benefits in the areas of Asia, Africa, Europe, and Oceania. Among versatile administrator bunches internationally, Vodafone positioned fifth by income and second (behind China Mobile) in the number of associations (469.7 million) starting at 2016 [10].

\section{ENVIRONMENTAL STRATEGY :}

Saving carbon by reducing travel intensity: In fiscal 2016, our efforts to invest in virtual collaboration technology along with strategic shifts in our delivery model by maximizing use of our Global Delivery Network reduced our air travel carbon emissions per employee by more than 10 percent from fiscal 2015. Thanks to the widespread use of collaboration technologies, continuing operational rigor in their delivery model, and an increased focus on virtual and regionalized training, they avoided more than 40,000 metric tons of CO2, saved more than US\$150 million in travel costs for Accenture and their clients, and improved work-life balance for their people around the world.

More efficient lighting and cooling: Accenture has identified enormous potential to make a difference in environmental sustainability by maximizing the use of new and digital technologies in our day-today operations. Frankfurt innovates with a smart LED hub For example, in fiscal 2016, Accenture installed a cutting-edge lighting system in their Campus Kronberg office in Frankfurt, Germany. The lighting system covers six floors, uses custom-manufactured LED ceiling-suspended luminaires, and is powered and controlled using Power over Ethernet (PoE). This eliminated the need for a traditional wiring installation and instead uses plug-and-play Ethernet cabling to power, control and relay information to the system's controllers.

Adding sensors to the system turned it into a smart LED hub where each luminaire collects information on ambient lighting, humidity, temperature and occupancy, and communicates it back to the central hub. Its flexible automated control also has eliminated the need for light switches. The system switches on and adjusts the lighting if someone occupies a space, and does the reverse when they leave.

Core hour and set-back programs ensure that the system operates at its most-efficient levels, and the daylight harvesting capability built into all the luminaires makes the most of daylight hours by 
adjusting intensity. The combined effect of LED, PoE and smart hub technology has helped reduce carbon emissions and increased energy efficiency.

\section{HR STRATEGIES :}

Accenture team collaborates or unites or combines with its customers spread all over the world to set up and coordinated projects to:

- Create an HR methodology that is firmly coordinated with both the business system and the human capital technique to help business results while conveying high-esteem ability and HR benefits that drive an enhanced worker and supervisor encounter.

- Design and execute an HR working model fit for conveying ability and HR benefits proficiently and adequately on a worldwide scale to help the basic needs of the business.

- Drive driving practices and operational greatness crosswise over ability and HR forms by adjusting those procedures to the HR working model and the hidden HR innovation design.

A coordinated HR methodology, a worldwide HR working model, and steady procedures can change HR into a finely tuned and deft association equipped for driving new levels of business esteem. Accenture is a pioneer and thought pioneer in the HR space. The wide-achieving research activity, "The Future of HR," has distinguished a few key attributes the HR work must create to enhance its effect on the business:

- Find intermediary new wellsprings of ability.

- Assemble a versatile and engaged culture.

- Apply science and actuality based investigation.

- Build up a learning association.

- Reclassify employments and profession ways to encourage inner and outer labourer versatility.

At last, Accenture can enhance their customer's HR capacities and their capacity to convey unsurprising, great HR administrations and at the same Accenture causes the HR associations to improve as a key cooperate with the business.

\section{COMPETITORS :}

IBM: The International Business Machines Corporation (IBM) is an American multinational innovation technology-based organization headquartered in Armonk, New York, United States, with its branches spread in more than 170 nations. The organization started in 1911 as the ComputingTabulating-Recording Company (CTR) and was renamed "Worldwide Business Machines" in 1924. IBM produces and markets PC equipment, middleware, and programming, and gives facilitating and Consulting or consultation administrations in regions going from centralized server PCs to nanotechnology. Accenture is principally a frameworks combination, Consulting and outsourcing organization. IBM Services gives a substantially more extensive scope of administrations. That is, the examination isn't exactly one type to its logical counterpart. In any case, Accenture is the nearest "peer" to IBM's Services business [9].

Capgemini Consulting: Capgemini is a French multinational expert administration and business Consulting organization headquartered in Paris, France. It gives IT benefits and is one of the world's biggest IT consulting, outsourcing and proficient administrations organizations with more than 200,000 representatives in more than 40 countries, of whom almost 100,000 are in India. It was established in 1967 by Serge Kampf in Grenoble, France.

Deloitte Touche Tohmatsu Limited: Deloitte Touche Tohmatsu Limited regularly alluded or called to as Deloitte, is a UK-joined or incorporated multinational expert organization or firm. Deloitte is one of the "Huge Four" bookkeeping associations and the biggest expert administrations arrange on the planet by income and number of professionals. Deloitte gives a review, impose, Consulting, venture chance and monetary warning administrations with in excess of 263,900 experts all around.

\section{STRATEGIES AGAINST ITS COMPETITORS :}

Accenture uses many strategies against its competitors to win over them and to sustain in the market. Some of the strategies are;

Switching costs: Accenture works with 91 of the Fortune Global 100 companies and more than three-quarters of the Fortune Global 500. These client relationships tend to be sticky. Accenture 
consultants work very closely with clients and learn a lot about the clients' businesses, and, over time, consultants become indispensable. Of Accenture's top 100 clients, 92 have been clients of Accenture for at least 10 years. These client relationships are also crucial as reference clients when bidding for new business.

Scale and scope: Accenture is one of the world's largest consulting firms, and it serves the world's largest organizations, the Global 2000. These clients operate globally and at a huge scale, and they need partners to operate at the same level. For instance, a typical systems integration project or outsourcing deal might require putting 50 or more experienced consultants on site, in addition to another 50 developers off-site. Only a handful of firms have the ability to operate at this scale, which generates pricing power for those handfuls of firms. Accenture has a very broad offering of services - from up-front McKinsey-type strategy consulting to back-end outsourcing. Thus, Accenture can honestly offer clients a one-stop shop to improve their business. In Accenture-speak, it's called "transformation," which is a holistic approach to solving business problems. Very few if any other firms have Accenture's broad scope of capabilities to go from development of a business solution through to implementation, including expertise in business processes, industry issues, technology, and back-office functions.

Intellectual property: Accenture has multiple delivery methodologies, playbooks, offerings, and the like. This is a codification of past work, which makes it easier and quicker to deliver new, similar work. As such, Accenture consultants don't walk into a new engagement empty handed -- they will be armed with an instruction manual. This allows the firm leverage intelligent, hard-working, junior people who tend to be inexpensive and high performers.

Brand: The Accenture brand was ranked No. 41 on Inter brand's 2013 list of the Best Global Brands. The brand conveys three distinct advantages. First, it offers downside-protection to CTOs and CIOs that hire Accenture. If an engagement goes wrong, they're not likely to take flak for hiring a no-name. If an Accenture engagement goes wrong, the CIO/CTO has the automatic out. Second, as a global brand, purchasing officers will seek out Accenture. As part of their job, they want to know someone at Accenture, and if a request for proposal is going out, Accenture will be included in the list. Third, and perhaps most importantly, Accenture's brand is a differentiator in the recruiting process. Juniorlevel hires want a brand-name on their resumes to start their careers, and senior-level hires, rainmakers that exist in small numbers, want to be selling a premier service. Accenture does face competition, but this combination of factors gives the company an edge that allows it to generate economic profits, even in the face of competition.

\section{SWOT ANALYSIS :}

The Accenture can be analyzed using Strengths, Weaknesses, Opportunities, and Challenges by considering different aspects [20-34].

\section{Strengths in the SWOT analysis of Accenture:}

- World's biggest consulting organization: as far as income it's the world's biggest Consulting or consulting organization which for the most part centers around IT and business consultancy. It has fabulous business morals and uncompromising benchmarks for superior.

- Strong Clientele: It has an expansive customer base with some first-class organizations having Accenture as their specialists. About 90 out of the fortune top 100 organizations and in excess of seventy-five percent of fortune worldwide 500 organizations have Accenture as a consulting organization.

- Service Delivery Network: Accenture has worldwide administration conveyance coordinate with nearness in excess of 200 urban communities, 56 nations and utilizing 390,000 enthusiastic representatives ceaselessly attempting to give ideal administration conveyance to end clients.

- Client-Driven procedures: The strong business relations and customer-driven approach initiated and maintained by Accenture causes them in making industry based, supportable incentive for their Consulting accomplices.

- Continuous change: Like Kaizen of Toyota, Accenture is continually looking towards enhancing its abilities, contracting better and more capable labour, accordingly coordinating their guarantee to the end clients. 
- Diverse abilities: With its five working gatherings specifically interchanges, Media and innovation, budgetary administrations, wellbeing \&public administrations and item assets it has made various capacities inside its group. Committed and prepared labour for every vertical is the thing that separates Accenture from the rest.

- Expertise: With its customer base extending from social insurance to vehicle to IT benefits, Accenture has a ton of experience and the ability behind it to complete things. Thus, Accenture has turned into the "authority" or "specialists" crosswise over various ventures.

Weaknesses in the SWOT analysis of Accenture:

- Lack of coordination: Accenture has 19 specialty units cooperatively working with the customers and with each other. This prompts clashes because of the absence of inward coordination.

- Dependency on its Consulting/consulting business: Although its business is in administration Consulting, innovation, and BPO, yet the Consulting part frames the significant wellspring of income for Accenture. This can be risky for the organization over the long haul since running such a huge task requires, to the point that the firm is prepared for terrible money related days.

\section{Opportunities in the SWOT analysis of Accenture:}

- Expansion of business: By focusing on little and fair sized ventures and extending to other creating economies (Market improvement), Accenture can build its income much more.

- Acquisitions: Accenture as of late gained 'Gaspo", an investigation arrangement supplier based out of Brazil. It likewise gained Agilex advances, which is a computerized and IT administrations supplier for U.S Govt. offices. Such acquisitions can build the scientific quality of Accenture along these lines helping it in development.

- Focusing on different organizations: More spotlight on innovation and BPO, and making the income comparable to consulting, can assist the firm in penetrating the market far and away superior. Likewise, this expansion will give a pad amid brutal monetary circumstances.

\section{Threats in the SWOT analysis of Accenture:}

- Competition: Tough rivalry from IT big companies like IBM, Capgemini, Infosys is the territory of worry for the organization.

- Improper and un-efficient monetary circumstances: During the subsidence time frame it was intense for the organization due to over reliability on premium customers. The vast customers were the initial ones which got influenced severely by the budgetary downturn. What's more, thus the income drive to Accenture dropped gravely.

\section{CONCLUSION :}

In this paper, we have discussed the main reasons for the sustainable growth of Accenture in the world market. The company business strategy is a model for other companies in this industry and teaches that every company should follow the long-term goal, planning, correct decision making at right time, maintaining good relations with employees, customers and stakeholders for prosperous growth. Further, building team co-ordination in a correct way, use of better technologies in production and making the right decision at right time to improve the product are essentials for a sustainable company. These points are useful for the success of the organization in the market. The Accenture business strategies are discussed as per the guidelines are given in Company analysis case study methodology [35-39] to understand its sustainable business strategy.

\section{REFERENCES :}

[1] Chang, S., \& Marks, S. (2000). U.S. Patent No. 6,105,012. Washington, DC: U.S. Patent and Trademark Office.

[2] Merriam, S. B. (1988). Case study research in education: A qualitative approach. Jossey-Bass.

[3] Gunasekaran, A., Forker, L., \& Kobu, B. (2000). Improving operations performance in a small company: a case study. International Journal of Operations \& Production Management, 20(3), 316-336.

[4] Yin, R. K. (2011). Applications of case study research.

[5] McWilliams, A. (2000). Corporate social responsibility. Wiley Encyclopedia of Management. 
[6] McGuire, J. B., Sundgren, A., \& Schneeweis, T. (1988). Corporate social responsibility and firm financial performance. Academy of management Journal, 31(4), 854-872.

[7] Porter, M. E., \& Van der Linde, C. (1995). Green and competitive: ending the stalemate. Harvard business review, 73(5), 120-134.

[8] Delmas, M. (2001). Stakeholders and competitive advantage: the case of ISO 14001. Production and Operations Management, 10(3), 343-358.

[9] https://www.seekingalpha.com/article/3221626-ibm-services-versus-accenture-a-by-the-umberscomparison. Accessed on 10-05-2018.

[10] https://www.en.wikipedia.org. Accessed on 10-05-2018.

[11] Fidel, R. (1984). The case study method: a case study. Library and Information Science Research, 6(3), 273-288.

[12] Yin, R. K. (1992). The case study method as a tool for doing evaluation. Current Sociology, 40(1), 121-137.

[13] Stake, R. E. (1978). The Case Study Method in Social Inquiry. Educational researcher, 7(2), 5-8.

[14] Stake, R. E. (1983). The case study method in social inquiry. In Evaluation models (pp. 279286). Springer Netherlands.

[15] Flyvbjerg, B. (2006). Five misunderstandings about case-study research. Qualitative inquiry, 12(2), 219-245.

[16] Gerring, J. (2004). What is a case study and what is it good for?. American political science Review, 98(02), 341-354.

[17] Runeson, P., \& Höst, M. (2009). Guidelines for conducting and reporting case study research in software engineering. Empirical software engineering, 14(2), 131.

[18] Bowen, G. A. (2009). Document analysis as a qualitative research method. Qualitative research journal, 9(2), 27-40.

[19] Noor, K. B. M. (2008). Case study: A strategic research methodology. American journal of applied sciences, 5(11), 1602-1604.

[20] Aithal, P. S., Shailashree, V. T., Preethi, J. \& Suresh Kumar, P. M. (2015). Leader with Golden Heart -- Sri CA. A. Raghavendra Rao (A Case Study). International Journal of Research in Management \& Social Science, 3(1). (IV), 96 - 102.

[21] Aithal, P. S. \& Acharya, R. K. (2016). Strategic Management Models \& Indian Epics, International Journal of Management Sciences and Business Research (IJMSBR), 5(4), 180-188, DOI: $\underline{\text { http://doi.org/10/.5281/zenodo.161093. }}$

[22] Aithal, P. S. (2017). An Effective Method of Developing Business Case Studies based on Company Analysis. International Journal of Engineering Research and Modern Education (IJERME), 2(1), 16-27. DOI: http://dx.doi.org/10.5281/zenodo.400579.

[23] Reshma, Aithal P. S., Shailashree V. T., Sridhar Acharya, P. (2015). An Empirical study on working from home - A popular E-business model. International Journal of Advance and Innovative Research, 2(2), 12-18. DOI : http://doi.org/10.5281/zenodo.164429.

[24] Aithal, P. S., \& Suresh Kumar, P. M. (2016). Theory A for Optimizing Human Productivity. IRA International Journal of Management \& Social Sciences, 4(3), 526-535. DOI: http://dx.doi.org/10.21013/jmss.v4.n3.p2.

[25] Reshma, Aithal, P. S \& Sridhar Acharya, P. (2015). Relevance of On-line Office Administration through Working from Home in Future Education System. International Journal of Application or Innovation in Engineering \& Management, 4(4), $44-53$. DOI: http://doi.org/10.5281/zenodo.163882. 
[26] Padmanabha Shenoy, and Aithal P. S., (2016). A Study on History of Paper and possible Paper Free World. International Journal of Management, IT and Engineering (IJMIE), 6(1), 337-355. DOI: http://doi.org./105281/zenodo.161141.

[27] Aithal, P. S. (2015). Comparative Study on MBA Programmes in Private \& Public Universities A case study of MBA programme plan of Srinivas University. International Journal of Management Sciences and Business Research (IJMSBR), 4(12), 106-122. DOI: http://doi.org/10.5281/zenodo.163884.

[28] Aithal P. S., and Suresh Kumar P. M., (2016). Analysis of Choice Based Credit System in Higher Education. International Journal of Engineering Research and Modern Education (IJERME), 1(1), 278-284. DOI: http://doi.org/10.5281/zenodo.161046.

[29] Varun Shenoy and Aithal, P. S. (2016). Changing Approaches in Campus Placements - A new futuristic Model. International Journal of Scientific Research and Modern Education (IJSRME), 1(1), 766 - 776. DOI : http://doi.org/10.5281/zenodo.160966.

[30] Aithal, P. S. \& Shubhrajyotsna Aithal, (2016). A New Model for Commercialization of Nanotechnology Products and Services. International Journal of Computational Research and Development, 1(1), 84-93. DOI: http://doi.org/10.5281/zenodo.163536.

[31] Shubrajyotsna Aithal \& Aithal, P. S., (2016). Student Centric Learning through Planned Hardwork - An Innovative Model. International Journal of Scientific Research and Modern Education (IJSRME), 1(1), 886-898. DOI: http://doi.org/10.5281/zenodo.61830.

[32] Aithal, P. S. (2017). Industry Analysis - The First Step in Business Management Scholarly Research. International Journal of Case Studies in Business, IT and Education (IJCSBE), 2(1), 113. DOI: http://dx.doi.org/10.5281/zenodo.810347.

[33] Aithal, P. S. (2017). An Effective Method of Developing Business Case Studies Based on Company Analysis. International Journal of Engineering Research and Modern Education (IJERME), 2(1), 16-27. DOI: http://dx.doi.org/10.5281/zenodo.400579.

[34] Aithal, P. S., (2017). Company Analysis - The Beginning Step for Scholarly Research. International Journal of Case Studies in Business, IT and Education (IJCSBE), 1(1), 1-18. DOI: http://dx.doi.org/10.5281/zenodo.573769.

[35] Aithal, P. S., (2017). ABCD Analysis as Research Methodology in Company Case Studies. International Journal of Management, Technology, and Social Sciences (IJMTS), 2(2), 40-54. DOI: http://dx.doi.org/10.5281/zenodo.891621.

[36] Jithin Raj, K. \& Krishna Prasad, K. (2018). A Critical Study on Business Strategies of 3i Infotech Ltd. International Journal of Case Studies in Business, IT and Education (IJCSBE), 2(1), 13-21. DOI: http://dx.doi.org/10.5281/zenodo. 1247319.

[37] Sneha, M. S. \& Krishna Prasad, K. (2018). Analysis of Business Strategies of Salesforce.com Inc. International Journal of Case Studies in Business, IT and Education (IJCSBE), 2(1), 37-44. DOI: http://dx.doi.org/10.5281/zenodo.1252028.

[38] Sudharshan Prabhu S. \& Vaikunth Pai T. (2018 May). A Study on Product and Services of HCL Technologies. International Journal of Case Studies in Business, IT and Education (IJCSBE), 2(1), 45-53. DOI: http://dx.doi.org/10.5281/zenodo.1253722.

[39] Madhushree, Revathi R., Anil Kumar, \& Aithal, P. S. (May 2018). Business Strategy of Top Indian IT Company: MindTree. International Journal of Case Studies in Business, IT, and Education (IJCSBE), 2(1), 22-36. DOI: http://dx.doi.org/10.5281/zenodo.1249871. 